\title{
Teaching Video NeuroImages: Spontaneous Third Ventriculostomy
}

Maud P. Tijssen, MD, Erwin M.J. Cornips, MD, and Joost Nicolai, MD, PhD

Neurology ${ }^{\circledR}$ 2021;96:e1266. doi:10.1212/WNL.0000000000010843

Figure Midline Sagittal MRI

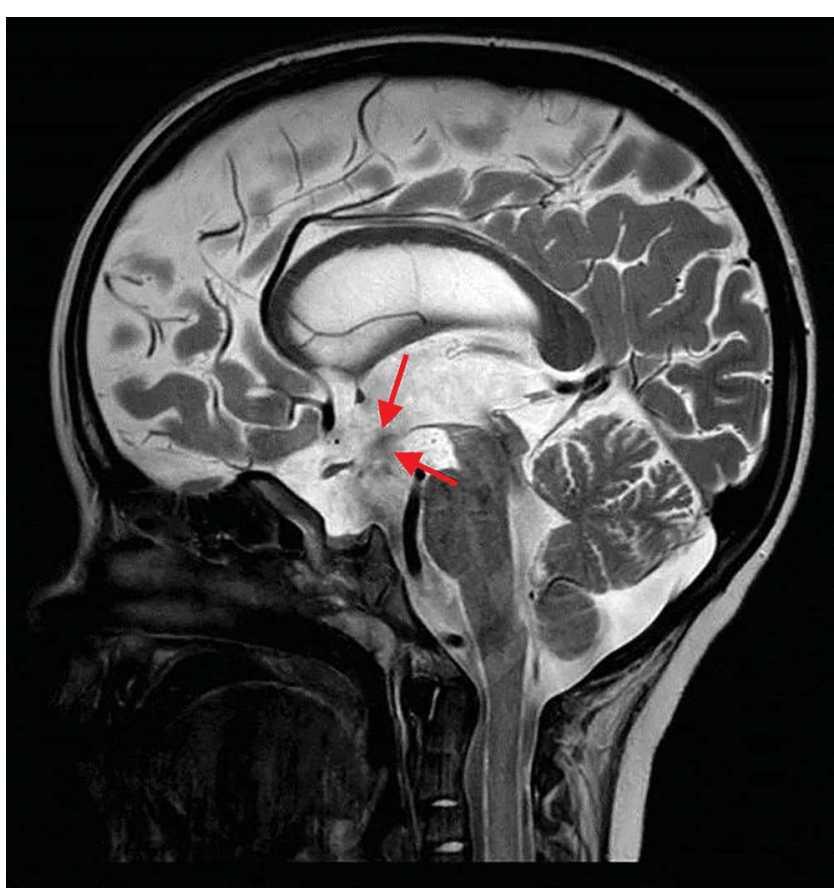

Sagittal heavy T2-weighted midline image. Small flow void (between arrows) can be identified at the floor of the 3rd ventricle.

A 4-year-old boy with macrocephaly (+3 SD) was evaluated with MRI, which showed a subdural hygroma secondary to rupture of a left temporal arachnoid cyst and triventricular enlargement. Two years later, we repeated imaging to explore the possibility of a third ventriculostomy. There was a flow void across the floor of the third ventricle (figure). By using 3D cardiac-gated dynamic imaging, we demonstrated that a spontaneous ventriculostomy had already occurred (video, links.lww.com/WNL/B217). Spontaneous third ventriculostomy is rare and can occur in children and adults with chronic hydrocephalus. ${ }^{1}$

\section{Study Funding}

No targeted funding reported.

\section{Disclosure}

The authors report no disclosures relevant to the manuscript. Go to Neurology.org/N for full disclosures.

\section{Reference}

1. Ogrenci A, Eksi MS, Koban O. Spontaneous third ventriculostomy 8 years after diagnosis of obstructive hydrocephalus. Childs Nerv Syst 2016;32:1727-1730.

\section{Correspondence}

Dr. Nicolai

j.nicolai@mumc.nl
MORE ONLINE

- Video

\section{$\rightarrow$ Teaching slides}

links.lww.com/WNL/

B216

From the Departments of Radiology (M.P.T.), Neurosurgery (E.M.J.C.), and Neurology (J.N.), Maastricht University Medical Center, the Netherlands. 


\section{Neurology}

\section{Teaching Video NeuroImages: Spontaneous Third Ventriculostomy \\ Maud P. Tijssen, Erwin M.J. Cornips and Joost Nicolai}

Neurology 2021;96;e1266 Published Online before print September 9, 2020

DOI 10.1212/WNL.0000000000010843

This information is current as of September 9, 2020

\section{Updated Information \&} Services

\section{References}

Subspecialty Collections

Permissions \& Licensing

Reprints including high resolution figures, can be found at: http://n.neurology.org/content/96/8/e1266.full

This article cites 1 articles, 0 of which you can access for free at: http://n.neurology.org/content/96/8/e1266.full\#ref-list-1

This article, along with others on similar topics, appears in the following collection(s):

All Pediatric

http://n.neurology.org/cgi/collection/all_pediatric

Brain trauma

http://n.neurology.org/cgi/collection/brain_trauma

Hydrocephalus

http://n.neurology.org/cgi/collection/hydrocephalus

MRI

http://n.neurology.org/cgi/collection/mri

Information about reproducing this article in parts (figures,tables) or in its entirety can be found online at:

http://www.neurology.org/about/about_the_journal\#permissions

Information about ordering reprints can be found online:

http://n.neurology.org/subscribers/advertise

Neurology ${ }^{\circledR}$ is the official journal of the American Academy of Neurology. Published continuously since 1951, it is now a weekly with 48 issues per year. Copyright () 2020 American Academy of Neurology. All rights reserved. Print ISSN: 0028-3878. Online ISSN: 1526-632X.

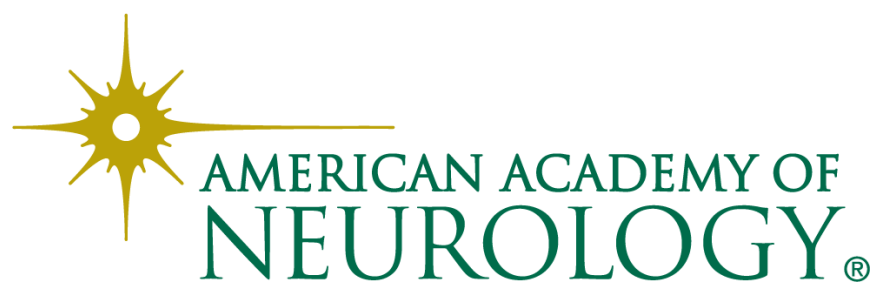

